\title{
ASPECTS OF URBAN SAFETY IN THE PUBLIC SPACES IN BELGRADE, SERBIA: RECOMMENDATIONS OF URBAN-ARCHITECTUAL PREVENTIVE ELEMENTS
}

\author{
UDC 711.4:699.8(497.11)=111
}

\section{Nataša Danilović Hristić}

Institute of Urbanism Belgrade, Serbia natasa.danilovic@urbel.com

\begin{abstract}
Contemporary urban planning and design is closely associated with the theory of safety. Researching the elements of fear of physical urban environment, the focus is on the prevention, which can reduce or eliminate negative perceptions of the users. Determining the standards for furnishing classified urban public spaces, could contribute to higher quality and use that is more intensive.

This paper incorporates the information provided by the relevant institutions and the poll of the citizens in Belgrade, as well as analysis of spatial urban elements, typology of their use and their condition from the aspect of safety. Finally, it provides some recommendations for urban planning measures and architectural design elements.

The practical application of the results relates to creation of information base, monitoring of changes, elimination of consequences, promotion of urban planning and architectural design profession, realization and maintenance of public places and creating the legal framework.
\end{abstract}

Key words: housing unit, flexibility, evaluation, multicriteria analysis.

\section{INTRODUCTION}

The relation between the planned and implemented in the urban planning practice in Belgrade has been debatable for quite some time. Although it is considered that urban planning on the territory of Belgrade has a tradition and that it has shown results, the discontinuity and inconsistency in the implementation of planning documents is apparent, their lack of respect and the fact that due to poor perception of priorities and interests the plans "do not produce" fast enough and in advance. Chaotic social system, followed by constant political and economic instability has certainly been translated to the spatial level of the city, which naturally must not be an excuse. On the other hand, the plans of previous epochs have been criticized for its determination, which did not correspond to real conditions, needs and abilities, and have therefore remained unimplemented. Modern ur- 
ban plans are based on more extensive research, after the European models, through studies and analyses prepared that should clearly indicate the existing space deficiencies and potentials, and in further phases verify the solutions proposed and provide creative development. If urban safety has been set as a goal, it is necessary to define the current condition and specify the factors that affect the reduction of a feeling of security by associating them with specific spaces. In order to prepare a strategic plan that covers the territory of Belgrade, a series of researches and analyses of available data at disposal to the numerous city institutions have been conducted, the evaluation of the existing situation has been made and targets provided for future development, which are of great importance for this study since they provide a range of information on average condition and further expectations. These data, related to the current situation and planned spatial and socio-economic development of the city, are important for considering the possibilities of setting another development goal - a safe environment for living.

In order to better perceive the socio-economic context of Belgrade, the Master Plan of Belgrade provides the overview of the social development, which partly explains also the attitude of the present citizens to urban life:" In the development of society in terms of urbanization, in the past, one may differentiate rural, industrial and urban characteristics of the society and the city. By degree of urbanization our society is still at the bottom of the list of Central and Eastern European countries. The share of urban population in total population, only in the early 1990 s exceeded the half (53\%), where, from demographic viewpoint, we became predominantly an urban society [1]."Demographic data provide a clear image of the rapid growth of urban population as a result of immigration, but also of mortality and drain of the young people, which classifies our society in the category of old populations. It can be concluded that Belgrade is on the way of becoming a metropolis in terms of the regional center, owing to its size, importance and numerous functions and activities, although, from historical viewpoint, this development has encountered many obstacles, which have slowed it, down significantly. Aspiring to take a prominent position on the map of Europe, the city must find a way to leave the" provincial" habits and style behind, while at the same time preserving its unique identity and charm. According to the Tourist Organization of Belgrade in the first five months of 2009, the number of foreign tourists was greater by nine percent than in the same period last year [2]. The visit to Belgrade is on the upscale, and generally, stated reasons are good amusement and entertainment, cultural and sports events, conference tourism and so on.

\section{APPLICABILITY OF THE LEGAL AND PLANNING FRAMEWORK}

Pursuant to the Constitution of the Republic of Serbia of 2006 [3], being the supreme legal document of a state, the rights of citizens were defined, especially the right to life, dignity and free development of personality, human and minority rights and freedoms, inviolability of the physical and mental integrity, the right to freedom and safety, freedom of movement, non-discrimination, prohibition of racial, ethnic and religious hatred and regulated status of the foreigners. The Law on Planning and Construction of 2009 as a legal act related to the topic of urban planning, does not address the topic of safety in urban public spaces, except that it addresses the requirements for equal accessibility. This field has also been directly and indirectly affected by implementation of: the Law on Amendments to the Criminal Code of 
2005, the Anti-Discrimination Act of 2009, the Law on Prohibition of Manifestations of Neo-Nazi or Fascist Organizations and Associations and the prohibition of use of Neo-Nazi or Fascist symbols and hallmarks of 2009, the Law on the Amendment of the Law on Prevention of Violence and Misbehavior at sports events of 2003, the Police Act of 2005, the Law on Offences of 2005 and the Act on Communal Police of 2009. The current By-law, which specifies the standards and norms related to the accessibility, is the Regulation on conditions for planning and design of the buildings related to unobstructed movement of children, the elderly, the handicapped and disabled dating 1997.

In conclusion, it could be pointed out that the existing legal framework provides a general possibility for the application of preventive measures and increase of the level of safety of the citizens in times when using the public spaces, because there are no legal obstacles and contradictions in the viewpoints. On the other hand, there is no legal obligation to implement these measures, especially not from the aspect of urban planning and design, except for measures related to the principle of accessibility. Until the eventual creation of the legal framework in the form of ordinances or regulations, it is possible to work on education of both the professional sector, and also the citizens and the decision makers, and to propagate this principle and advocate in public, to cooperate with police but also with the non-government organizations and in accordance with the possibilities, introduce applicable rules and standards in urban document by own professional authority, especially in the segments related to regulation of the public areas and spaces.

The current Master Plan of Belgrade dating 2003 covers the territory of 12 urban municipalities, i.e. about $80 \%$ area of administrative boundaries of the municipalities or 77.602 ha. They are included as per the character of different space units, from the central urban zones to peripheral rural areas (the central zone $-3,206$ ha, the middle zone -8.532 ha, the external zone - 21.962 ha and the peripheral zone - 43.902 ha), which comprise a variety of topographic, morphological, typological, economic and social characteristics and components. The planned population is 1.4 million, with time projection of the plan until 2021.

On the territory of the City of Belgrade, there are about 500 current detailed urban plans. This type of plans is adopted for settlements or parts of settlements and as per the spatial coverage, i.e. per the area, it can be rather diverse, which on the example of Belgrade ranges from 1 ha to 750 ha. The minimum coverage is one city block with appertaining traffic routes. In the total summary, the detailed urban plans cover about $65 \%$ of the urban space intended for construction. Substantially, these plans closely determine the use of space, the routes and corridors of roads and infrastructure, horizontal and vertical regulation, capacities and building codes, rules of parceling out, special conditions associated with the preservation of culturalhistorical heritage and environment and the manner of further implementation. In preparing them particular care has been taken of the application of urban standards for public spaces and uses. Legally defined procedure of plan preparation involves also the cooperation with all relevant institutions, organizations and utility services, comprising also obtaining adequate conditions and approvals to the planned solution. In addition, except for the expert controls, the plans are presented for the public hearing as well, where citizens can provide their comments to the solutions proposed. Since the existing detailed urban plans date from different periods of their preparation, on several occasions they were re-examined in terms of their compatibility with the new legislation, compliance with the plans of a higher order that are relatively recently dated, the condition in the field i.e. degree of implementation, new requirements and the like. 


\section{Characteristics of Urban Public Spaces of Belgrade}

The emergence and historical development of the public spaces in Belgrade is best to be freely studied in the area of the historical core of the city, i.e. in the part of the central area [4]. The need for reconstruction of oriental Belgrade presented itself after 1862, at the same time when in many European cities (Paris, London, Vienna and Barcelona) comprehensive and radical reconstructions were under preparation or in progress being the consequence of the industrialization process. The complete transformation of Belgrade borough had a different cause, goal and symbolic, however, it was implemented after the European model. The plan of Emilijan Joksimovic was radical, it set the completely new orthogonal traffic network, which would permanently determine physiognomy of the central zone of Belgrade, by forming regular urban blocks and defining the public spaces.

Urban public spaces of Belgrade today are fundamentally no different from the same ones in other cities, even for their diversity, location and interaction they have great potential for further development and improvement. According to generally accepted opinion, one of the greatest qualities of Belgrade public spaces is made by their users, the citizens who in different ways, whenever weather conditions permit, visit the open urban spaces, socialize and enjoy in that which they have to offer. Belgrade squares, street cafes gardens, pedestrian zones, parks, urban forests and picnic sites, rivers and coastal zones, the beach of the artificial lake of Ada Ciganlija and biking trails are only some of traditionally visited and gladly used urban spaces. The Belgraders are accustomed to mutually sharing good and bad in the urban spaces environment, to celebrate victories (e.g. welcoming winning athletes), the New Years, running the marathons, roller skating, listening to concerts but also to protest and express their disapproval. In a survey conducted in Belgrade by the Bureau team of the architect Jan Gehl 2008 [5], it was concluded that the city possessed the culture of frequent use of public space, adjusted to the climatic region, and that attention should be paid to their development, so as not to lose the valuable habits and a positive effect of their use and have the vitality of the city redirected over to the enclosed malls and similar places. In Belgrade circumstances, compared to the budgetary resources of other cities, the investment in furnishing and maintenance of the public urban spaces is rather modest. Besides, if retrofitting of public spaces has been proposed in order to increase the level of safety, one should bear in mind the diversified organizational structure, shared re-

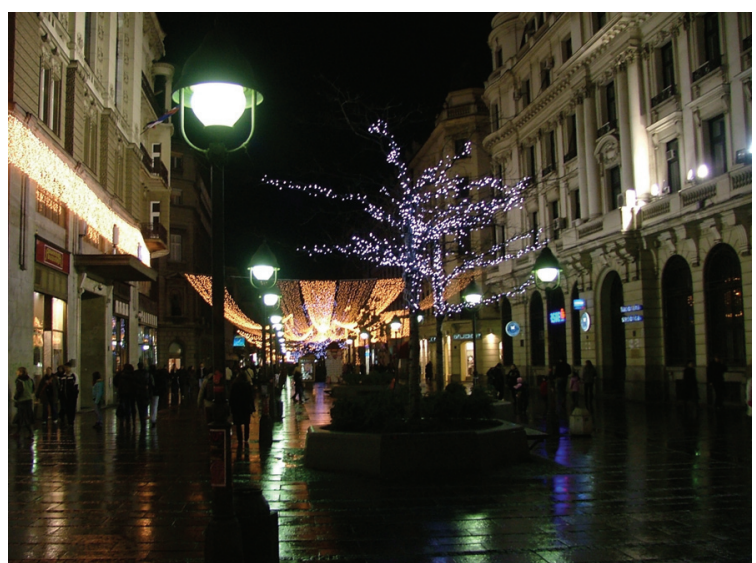

Fig. 1. Pedestrian zone of Knez Mihailova Street by night, with decorative lighting

sponsibilities and a lengthy process of decision-making and execution. For this reason, it is necessary to consider the minimum level of equipment that will provide optimal results. 


\section{4. inVestigation of the Users Perception of Urban Public Space}

On the territory of Belgrade until recently there were no specific studies on the subject of safety of the users of urban public space, especially in terms of urban planning and design. For many years, Belgrade has been considered a safe and secure city, with an average crime rate for the capital of one million inhabitants, a successful organizer of the international conferences, open and warm to the tourists. The events during the $1990 \mathrm{~s}$, the difficult political and economic situation, life in a war environment and degradation of social norms and standards, have introduced some changes. It was not until the middle of the last decade that studies were conducted on this topic from the viewpoint of sociology and criminology [6].

The Institute for Sociological Researches of the Faculty of Philosophy in Belgrade [7] prepared a study in the period 2003-2004 on the theme of safety and risk sources in the neighborhood from the perspective of children and their parents. From the spatial aspect, the survey was conducted in three parts of the city; through a survey, the results were obtained which testify of a high degree of coinciding perceptions of the children and the parents in identifying the issue of the reduced safety level. The most frequent risk sources are the presence of drug addiction in the spaces planned for the stay and play of children, unilluminated space and disorder in the space, suspicious unknown individuals and bullying. On three occasions, in 2004, 2007 and 2008 the Institute for Political Studies, Center for Security Studies and Terrorism Research studied the attitude of the citizens when it concerned the feeling of safety in the capital. Certain publications of the Institute for Criminological and Sociological Researches can be consulted in terms of understanding the topic and its importance. In addition to the above researches the topic of safety in a broader sense, is dealt with by a number of non-governmental organizations - OSCE Mission to Serbia and UN-HABITAT.

Based on the data and information available to the Ministry of Interior of the Republic of Serbia - Secretariat of Belgrade and non-government organizations (SOS telephones, legal aid, trauma center, safe houses, etc.), an impression can be obtained on the cases of violence in urban public spaces [8]. Narrowing down the analysis of the data to one specific society group - women, the image was obtained of vulnerability, according to the traditional understanding as a sensitive and easily vulnerable population groups, which at the same time is rather active and mobile, and in Belgrade makes a significant proportion of the population (according to the census from 2011. about 53\% of the capital population are women). Based on data obtained from the MIA RS - Secretariat of Belgrade, a review of criminal acts against women on the territory of ten city municipalities of Belgrade was created and which were committed exclusively in public areas, in the period from 2000 to 2005 , when 2135 cases of robbery of women were recorded and also the declining trend of this type of crime was observed.

The information about the attitude of the citizens of Serbia towards safety is a result of the public opinion poll on police reform in Serbia, which was conducted by OSCE and IPSOS Strategic Marketing. The survey was conducted in two phases (in November 2008 and October 2009), on the total of 2990 respondents, aged over 18 and by "face to face" method. The question asked " Which problems do you think present the greatest threat to the security of the citizens in Serbia ?"; resulted with violence in public places as an answer taking the fifth place, with an increase of concerned citizens from 3\% in 2008 to $9 \%$ in 2009. Responses like: drug abuse (in the first place), crime (generally speaking, else- 
where), violence (in the fourth place) and minor offenses (in the sixth) are not negligible either, since they are all in some way associated with the level of safety in public places.

The research conducted in 2007-2008 by the team of Urban Planning Institute of Belgrade [8] involved the analysis of users' perception of space and its safety based on the survey of the citizens. This is a common way of information gathering, and the form, i.e. survey contents and the method of analysis and interpretations of the responses obtained were carried out in accordance with the similar surveys conducted in other European cities. The main aim of survey was determination of the personal feeling of safety of the citizens in public spaces, i.e. consideration of their personal perceptions associated with this issue as well as information gathering about which spaces in Belgrade are deemed less safe by the citizens, i.e. where they feel more vulnerable or exposed to danger. In order to obtain as clear indicators as possible, the survey was anonymous and was distributed to various categories of population, i.e. it was ensured to include the participation of both sexes, various generations, certain threatened and minority groups, as well as foreign citizens currently living and working in Belgrade. Essentially, the survey's parameters were defined after the similar surveys conducted in the cities worldwide, and the questions asked could be classified in three groups:

- Questions related to personal information on the respondents as well as their daily habits - sex, age group, and part of the city they live in, work and spend their leisure time, whether they belong to some of the specified social groups, what time of the day or night and which way they mostly move around the city [9].

- questions related to personal perceptions, feelings and experience - whether they do not feel safe enough in certain parts of the city, whether they avoid leaving the place of residence for fear and whether for that or some other reason their mobility has been endangered, whether they feel more secure when they are in company, whether they have personally experienced something unpleasant in public urban spaces, or someone close to them experienced the same and how they react when they witness an incident [10].

- Suggestions about which way safety in public spaces can be improved - level of trust in law-enforcement, selection of some of the proposed measures and space for providing suggestions and proposals [11].

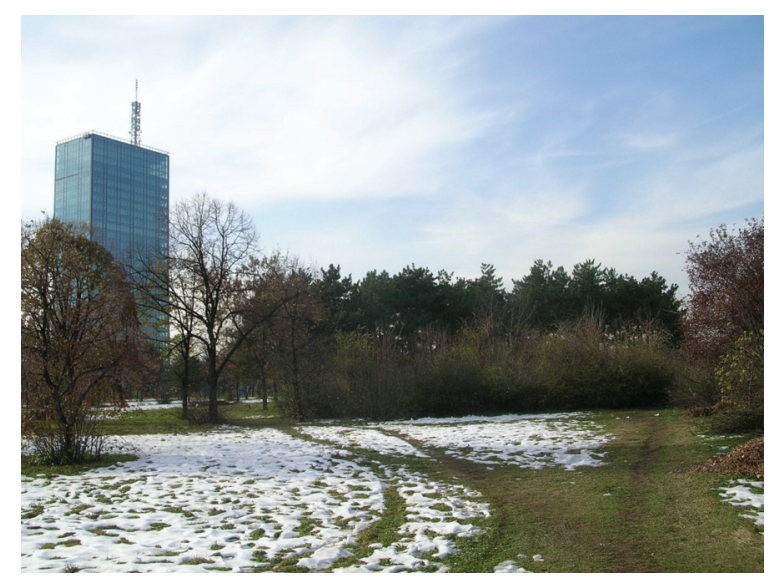

Fig. 2. Urban park on Ušće, New Belgrade 
This way data were obtained that the majority of citizens stay in the public spaces in the afternoon, between 12 and 19, and during the "active" part of the day, from 824 hours, there is $88 \%$ of stays outside the place of residence. It is interesting to note that most of the respondents take mobility in the public space to mean stay in the public space and leisure activities, like for instance walking the dog in the early morning, going to market or window-shopping on weekend mornings, stay in the park in the afternoon, walking downtown in the afternoon and evening, meeting with friends, going to an outdoor event (concert or other event), but not going to work or college.

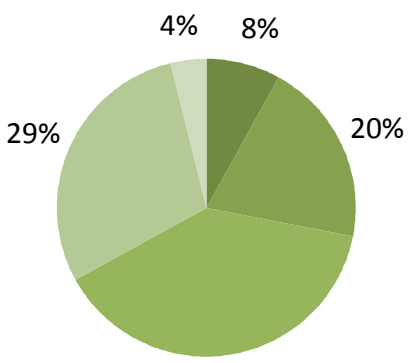

$39 \%$ early in the morning (4-8)

morning (8-12)

afternoon (12-19)

evening (19-24)

late in evening (24-4)

Fig. 3. The most frequent period of mobility in the open public spaces

Most of the respondents move in Belgrade on foot $(35 \%)$ or by some sort of public transportation $(36 \%)$, whereas about $24 \%$ use their own vehicle or taxi service. The smallest number of respondents ride a bicycle which can be attributed also both to unfavorable morphology of the terrain and the lack of adequate bike trails in greater number.

When answering the question whether the respondents avoided certain parts of the city, some settlements or parts of the space in fear for their own safety, half of the respondents opted for positive reply. In the explanation, the parts of the city or type of space were stated. Generally, it primarily concerned vast park spaces in which citizens did not feel comfortable when it got dark, then the areas primarily intended for traffic (highway loops, the area around the railway and bus stations, bridges, underground passages, public transportation stops) and peripheral settlements that by their typology belong to the open block, and also the areas with a great circulation of pedestrians were mentioned where due to crowds there came to decreased concentrations related to safety, which may present mitigating circumstances for minor criminal acts, such as theft. It is quite interesting that approximately the same number of respondents stated spatial and social problems as crucial for avoiding certain parts of the city. The relation between these two aspects is obvious, i.e. dark and unarranged spaces, according to the understanding of the citizens, automatically attract the individuals of deviant behavior (according to the survey's quotes: "homeless persons, alcoholics, junkies, skinheads, bullies") and present potential danger for all the rest. 


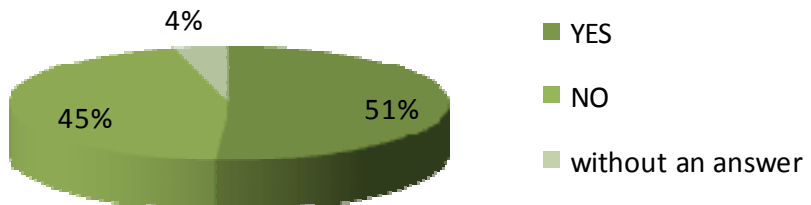

Fig. 4. Answers to the question: "do you avoid some parts of the city because of fear"

The mobility of the citizens, i.e. the undisturbed feeling of freedom and security in using urban public spaces is of great importance. To the question whether they avoided leaving the house (being the synonym of safe space) at certain time of the day, most respondents $(59 \%)$ answered that they did not, but close to one-half of them said that they avoided going out in the late hours at night. As regards the question what the citizens were afraid of, i.e. what prevented or restrained them to stay in certain urban public spaces during certain period of day and night, mostly quoted answers indicated to the combination of spatial and social problems, such as insufficiently illuminated spaces, desertedness i.e. absence of other users, or presence of persons who one can expect offences and violent attacks from. The feeling of greater security when in-group compared to when the individuals find themselves in urban public spaces does not significantly differ, $53 \%$ versus $45 \%$.

The next group of questions related to the personal negative experiences, which occurred in urban public spaces, and $69 \%$ of the respondents considered that they personally had had or had the knowledge that somebody close to them had had some sort of an unpleasant experience, from verbal attacks, insults and comments to physical attacks, thefts and other criminal acts. To the question how the citizens reacted when they happened to witness some sort of attack on the other person in the public space, the respondents even provided several variants of answers, having in view different situations they had found themselves in, as well as hypothetical standpoints on how they would act in those situations. Basically about $50 \%$ of citizens do not react, about $29 \%$ react actively, independently or with the help of the people present, while $21 \%$ of the respondents call police.

The third part of the survey was devoted to the proposals for safety increase, where the overwhelming majority of respondents, $98 \%$ of them, believed it was possible to implement the measures, which would lead to better public security in the urban areas. The greatest number of respondents, from 22 to $30 \%$, marked better lighting and more frequent patrols of law enforcement officials, as key measures. A large number opted for a different mode of public transportation, even also for video surveillance (12-13\%), which often is considered an unpopular measure because it is often associated with compromising the intimacy and privacy of the citizens. A smaller percentage, between 7 and $9 \%$ recognized problem in buildings orientation and arrangement of green areas, while the smallest number (3-4\%) chose the response offered related to the space good layout and fencing.

On the basis of the official data obtained, the research and surveys conducted and interviews with the citizens a conclusion may be reached that certain areas of Belgrade, namely the types of space and spatial elements and certain users of the mentioned spaces cause the feelings of fear and worry for personal safety. Based on these data the criteria for identifying potentially dangerous areas and their spotting on the map can be created. Thus marked "black spots" or stretches, as opposed to a network of spaces that have been evaluated as safe, provide the signal at which place it is necessary to implement any of the 
technical measures of prevention or to reinforce police supervision. The general conclusion is that the residents and the visitors of Belgrade still feel relatively safe in urban public spaces. They feel the safest in the areas that are "alive", frequented and well illuminated at night, or in some manner monitored, and they feel insecure near the areas with a large circulation of people or the presence of "risky groups" or in the spacious park spaces where there is not enough visitors. The feeling of insecurity is equally caused both by spatial

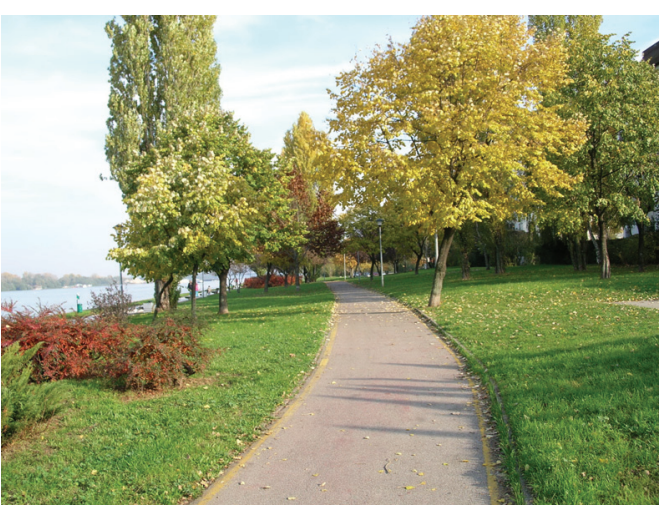

Fig. 5. Residential park by the river Danube

elements and by the presence of "unwanted persons", and the majority of citizens believe that there is interdependence, i.e. the spaces that are under-equipped and used to attract offenders or other persons who inspire fear (listed as: homeless, alcoholics, drug addicts, etc), which makes the space dangerous and undesirable, i.e. leads to the fact that it causes fear and people avoid it whenever possible.

At the time of conducting this research the majority of the respondents who participated did not know much about the topic of safety, i.e. they were not informed about the importance of this topic and its impact on the quality of urban life [12]. Also, preventive measures are not known to our citizens and are mostly identified with a greater presence of law enforcement with better night lighting and space surveillance [13]. At the same time almost half of the respondents were not prone to react to the observed criminal act or violence, and nearly half have no confidence in law enforcement. For this reason it is necessary to work on the education of the citizens on their being informed, active participation in planning and spatial development and building of trust in law enforcement.

\section{RECOMMENDATIONS OF URBAN-ARCHITECTUAL ELEMENTS FOR PROVIDING HIGHER LEVEL OF SAFETY}

As already mentioned above, safety is one of the aspects of quality of life in the society, where people, individually or collectively, and to a sufficient degree are spared from criminal acts and associated forms of behavior, and reassured about myths and well-informed about real risks related to criminal and prepared to bear with the consequences [14]. The feeling of the citizens that they are completely safe and carefree in urban public spaces has a positive and beneficial impact on the daily cultural, social and economic life of the city. The crime suppression is considered to be any single action or set of actions that have an impact on reducing the frequency and severity of criminal acts, and it is believed that the best results are achieved by application of measures of prevention, which act directly on the causes. It should be emphasized that prevention measures do not involve great investment and can be implemented already in the planning and design phase. In the next phase, it is important to estimate what the priorities for implementation are, what is viable to be carried out through mutual cooperation between citizens and experts 
in charge of safety. The practice has been to compare the wishes and perceptions of the citizens to the information at disposal to the authorities, and then, based on that to form a very clear image of which measures, at which locations and in what order should be applied. In order to enable the citizens to have an opportunity to participate and express their perceptions and fears, provide their opinions and ideas, it is recommended to the local government to conduct surveys or organize public forums. In addition to diagnosing problems in space and make the identification of needs, which has never been easy, the next step that requires special attention is the implementation and monitoring of measures, since following the decision on a set of appropriate measures after their implementation often remains a problem of maintaining the elements of urban design at a satisfactory level and its possible improvements based on shortcomings identified [15]. Therefore, achieving good results requires long-term and ongoing site management and maintenance of physical outcomes of the project. Regular maintenance of vegetation, lawns, paths and grounds, waste removal and graffiti cleaning, replacement of street furniture and lighting, is within the competence of the existing system of public communal services, but it is necessary to coordinate their work and pay more attention to safety aspect, which in fact can be easily achieved by regular maintenance of the spaces.

Urban planning can directly contribute to the prevention of crime through the application of tools such as development plans, supplementary planning guidelines, discussions and negotiations prior to their adoption, making decisions that control the development, planning conditions and obligations, working in partnership with the police and non-government organizations [16]. The suggested attributes can contribute to the sustainability of the community in terms of its safety through crime prevention: access and mobility, are associated with areas of well-defined routes, which allow communication, mobility, transit and stay without compromising safety, buildings spatial layout that prevent and minimize conflicts, spontaneous and uninterrupted natural monitoring of publicly accessible spaces, a sense of ownership and possession as well as belonging, togetherness, mutual respect and appreciation and territorial responsibility, physical protection, which in addition to safety features also possesses characteristics of a good design, the level of everyday human activities appropriate to the location, which reduces risk of crime and creates a feeling of safety in all situations and effective spaces management and maintenance. In an environment that is well planned, attractive, clearly defined and well maintained, people will feel proud of their environment, they will mostly feel comfortable and have a sense of shared possession and responsibility. Poorly planned environment provides a sense of alienation and fear, and unlike it, a well-planned environment contributes to the cohesion of the community and meets all planned functions in an efficient and harmoniously coordinated way.

The use of space makes one of the most important aspects, which affect the activities in space and therefore the security level as well. As mentioned before, the ideal is a city which is 24 hours alive i.e. which consists of the combination of diverse uses (dwelling, business, commercial, public uses), of moderate density, clearly defined relation between the private and the public, well-planned and projected directions of movement, which provide constant and equal circulation of the inhabitants and reduce the risk of the space being deserted at some point. Also, compactly developed spaces without uninhabited areas and voids, are by far more favorable. It is desirable to orientate the buildings in such way so that the rooms where the most time is spent provide an easy-to-survey street or other public spaces view, fencing the land for better visual survey should be of less height 
or if high to provide satisfactory level of transparency. In order to be considered a safe space it has to be easily accessible, easy-to-survey, provided with alternate directions for movement and well-marked signalization, well illuminated and surveillance, as needed. In that respect, the starting point is planning and designing, having in mind activities and functions, identifiable benchmarks and views, unique image of settlements or certain buildings, clearly visible and moderately long directions of movement, but also the elements of urban furniture. The quality and well-designed furniture is by itself an obstacle to vandalism. Likable and authentic design makes citizens feel proud and intensify the feeling of identity with their own city while disdain to bad design reflects mostly on the elements themselves (benches, garbage baskets, sculptures or public transportation stops).

In the recent years, Belgrade has ensured to take care of this aspect and in accordance with its financial means to keep up with the trends. The recommendation for the city of Belgrade is certainly to pay more attention to design, placement and maintenance of urban furniture as well as to re-investigate public lighting in some areas i.e. to adjust it to comply with safety terms and conditions. In respect to video surveillance which is associated with controversial standpoints, maybe it would be the most appropriate to restrict it to a necessary minimum i.e. to those spaces where it is not possible to gain desired results with other measures or which present the constant neurological points. If the citizens would feel safer and would be free of fear of the potential unpleasantness and violence, and cameras would not cause in them some other sort of resistance to space or feeling of compromised privacy and freedom, then it can be considered a justified measure and positive solution [17].

The principle of accessibility is based on the same humanistic concepts and legal provisions guaranteeing equal rights for all citizens to freedom and which prohibit discrimination and exclusion on any grounds. The freedom of movement, the feeling of comfort include also the feeling of security and safety, and most of the measures, including also the technical ones, contribute to a different appearance, understanding, acceptance and manner of space usage. The concern about the public spaces, but also the concerns about all members of society, providing equal opportunities to all through the measures of adjustment, sharing space and enjoying life together, communication and a sense of belonging are the basis for creating a secure and safe environment. If the needs of the most vulnerable sections of society have been met (e.g. people with disabilities, the elderly, children or women), then the needs of all those who do

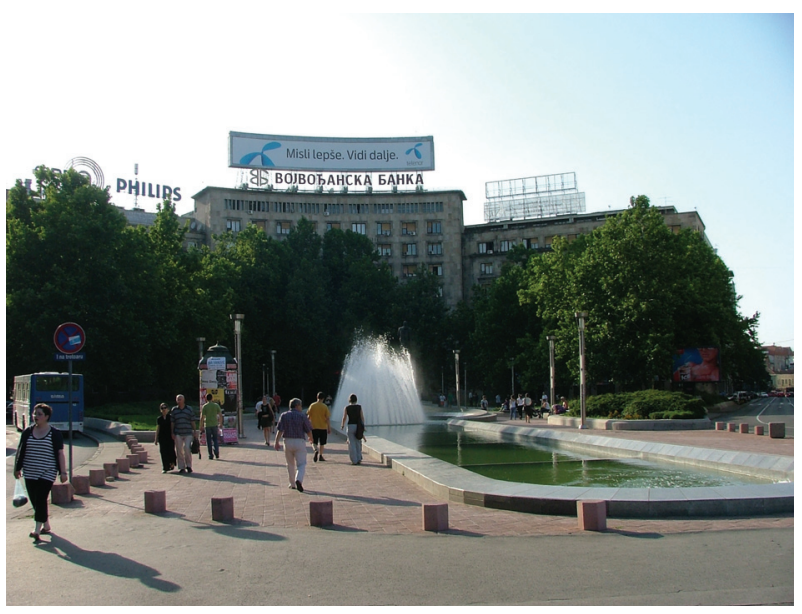

Fig. 6. Frequent use of public place, Square of Nikola Pašić not feel vulnerable or endangered will also be met, but they can easily become the same (vulnerable and endangered) if they are exposed to the inconvenience of a neglected and hostile environment. 


\section{CONCLUSION}

The measures of prevention applied in the phase of urban planning could contribute to more comfortable and freer space usage and the fear of urban structure could be reduced to fear of possible risky activities and incidents and the possibility for such events to happen exactly where the environment provides them the opportunity by its nature (e.g. neglected, isolated, badly laid, dark and similar spaces). The measures of prevention could be applied both to already built spaces through their reconstruction and adjustment to the influential factors, and also in the phase of planning new urban spaces, by application of the standards and spatial normative for its arrangement. In this way, with small additional investment, huge benefit can be achieved which registers in the more intensive use of urban public spaces but the surrounding functions as well, and resulting in the pleasure of the users, increased mobility, feeling of a higher level of security and belonging to the society and economic profit. These measures are less "imposing" and by far more agreeable than institutional controls of the space by surveillance of law-enforcements (uniformed officers, video cameras and so like).

An important characteristic of the public spaces is their integration and incorporation in the network system that allows for unrestricted movement and use. If any element of this network were considered by the users to be inadequate, unsafe or undesirable, it would result in its avoidance, i.e. exclusion from the matrix. In line of identification and diagnosis of problems, it is important to identify whether it concerned just a poor spatial organization, neglect and failure to maintain the space, the more profound sociological problem of settlements or a combination of all these problems. Depending on that measures are to be selected which are possible or necessary to implement. Since public spaces should present the priority in the process of urban planning, in terms of protecting the public interest and promotion of the overall quality of life, it is necessary to include more actively the segment relating to measures for safety and security into urban practice.

Analyzing the condition in Belgrade, based on the information gathered, including also the opinions of direct users it have been concluded that Belgrade is still a relatively safe city but also that measures should be taken which would contribute to the feeling of safety to still remain. The recommendations for further actions were certainly creation of the unique database in GIS technology, which could provide process monitoring in space, mapping of events and actions, registering of changes, making comparative analyses and analyzing the results of the application of positive measures of prevention. Education and specialization of

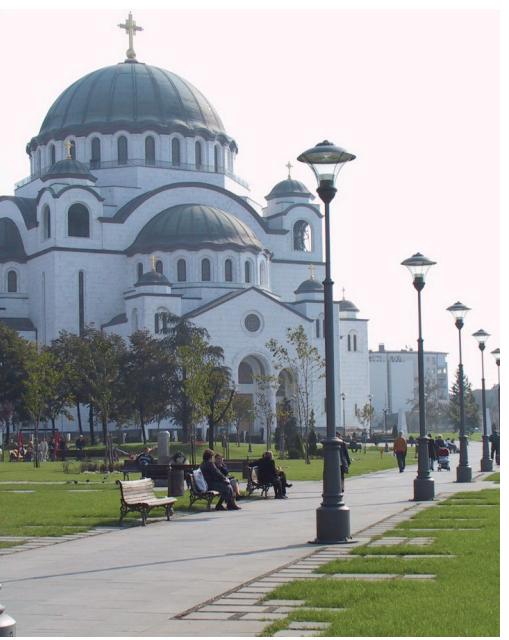

Fig. 7. Renewed public places: coherence with urban safety, St Sava church in Vračar. experts in these topics is preferable equally as general awareness of the citizens and their elected leaders. Considering that legal framework provides the possibility of application of urban-architectural measures of prevention, it is necessary to work on their standardization and creating by-laws or running professional publications. 


\section{REFERENCES}

1. JUP Urbanistički zavod Beograda: Generalni plan Beograda 2021, http://www.urbel.com

2. Turistička organizacija Beograda, http://www.tob.co.rs

3. Narodna skupština Republike Srbije, http://www.parlament.sr.gov.rs

4. JUP Urbanistički zavod Beograda,: Studija javnih prostora Beograda za potrebe urbanističkog planiranja, I faza - analiza javnih prostora Starog grada; Beograd, 2009.

5. Gehl Architects, Urban Quality Consultants: Port of Belgrade, Strategies and Guidelines for a Harbour Development; 2009

6. Danilović Hristić N.: Urbanističko-arhitektonski elementi za obezbeđenje višeg stepena bezbednosti na javnim gradskim prostorima; neobjavljena doktorska disertacija, odbranjena na Arhitektonskom fakultetu u Beogradu 2010.

7. Tomanović S. (ed.) Društvo u previranju - sociološke studije nekih aspekata društvene transformacije u Srbiji; Institut za sociološka istraživanja Filozofskog fakulteta u Beogradu, 2006.

8. Danilović Hristić N. (ed.): Sigurniji javni prostori, studija o bezbednosti javnih gradskih prostora u Beogradu; Urbanistički zavod Beograda i Misija OEBS u Srbiji, Odeljenje za demokratizaciju, Demsec projekat, 2008.

9. Holland C., Clark A., Katz J., Peace S.: Social interactions in urban public places; Joseph Rowntree Foundation, 2007.

10. Clarke R.V., Felson M. (ed.): Routine Activity and Rational Choice, advances in criminology theory, Volume 5; Transactions Publishers, 2004.

11. Wates N.: The Community Planning Event Manual; Earthscan, London, 2008.

12. Ortiz de Urbina Gimeno, I. \& Ponce Solé, J. (coord.): Convivencia ciudadana, seguridad pública y urbanismo, Diez textos fundamentales del panorama internacional; Barcelona, 2008.

13. Schneider R. H., Kitchen T.: Crime Prevention and the Built Environment; Routledge, London, 2007.

14. Maguire M., Morgan R., Reiner R. (ed.): The Oxford Handbook of Criminology; Oxford University Press, 2007.

15. Ordeig Corsini J. M.: Diseño urbano, accesibilidad y sostenibilidad; Instituto Monsa de Ediciones S.A., Barcelona, 2007.

16. Office of the Deputy Prime Minister \& Home Office: Safer Places - The Planning System and Crime Prevention \& Secured by Design Principles - Concept; London, 2004. Translation to Serbian: Bezbednija mesta - sistem planiranja i prevencija kriminala; Urbanistički zavod Beograda i Inženjerska komora Srbije, 2007.

17. Whitzman C.: The Handboook of Community Safety, Gender and Violence Prevention - Practical Planning Tools; Earthscan, London, 2008.

\section{ASPEKTI URBANE BEZBEDNOSTI U JAVNIM GRADSKIM PROSTORIMA BEOGRADA, SRBIJA: PREPORUKE URBANISTIČKO-ARHITEKTONSKIH PREVENTIVNIH ELEMENATA}

\section{Nataša Danilović Hristić}

Savremeno urbanističko planiranje i urbani dizajn blisko su povezani sa teorijom bezbednosti. Istražuju se elementi straha od fizičkog aspekta urbanih sredina, sa fokusom na prevenciji, koja može da doprinese smanjenju ili nestanku negativnih percepcija korisnika. Definisanje standard za opremanje određenih javnih urbanih prostora može da unapredi njihov nivo kvaliteta i intezivira upotrebu.

Ovaj rad inkorporira podatke dobijene od relevantnih institucija i rezultate ankete sprovedene među grašanima Beograda, kao i analize prostornih urbanih elemenata, načina i uslova upotrebe, sa aspekta bezbednosti.Finalno, daje set preporučenih mera za process urbanističkog planiranja i projektovanja.

Praktična upotreba rezultata odnosi se na formiranje informacione baze, monitoring promena $u$ prostoru, eliminisanje posledica, promociju urbanističkog planiranja i arhitektonskog dizajna kao profesije, realizaciju i održavanje javnih gradskih prostora i stvaranje zakonske osnove za primenu predloženih mera.

Ključne reči: urbanističko planiranje, dizajn, arhitektura, javni prostori, bezbednost, prevencija. 